\title{
CONSTITUTIONAL LAW: DELIBERATE INCLUSION OF NEGRO ON COURT-MARTIAL BOARD HELD CONSTITUTIONAL
}

$\mathrm{I}_{\mathrm{T}}$ $I_{T}$ is well established that the deliberate exclusion of members of a particular race from grand or petit juries is unconstitutional under the equal protection clause. ${ }^{1}$ In recent years, however, the converse practice of deliberate inclusion also has been challenged. ${ }^{2}$ In the related context of deliberate inclusion of a Negro on a court-martial board, the Court of Military Appeals has found the procedure constitutionally permissible.

In United States $v$. Crawford, ${ }^{3}$ a Negro enlisted man was specifically chosen to serve on a court-martial board because he was a member of the defendant's race. ${ }^{4}$ Asserting that racial criterion is unrelated to the qualifications of a court-martial board member, 5 the defendant on appeal objected to the procedure as a denial of equal protection. ${ }^{6}$ In a plurality opinion, ${ }^{7}$ the court held that the

1 U.S. Const. amend. XIV. See Arnold v. North Carolina, 376 U.S. 773 (1964); Eubanks v. Louisiana, 356 U.S. 584 (1958); Hernandez v. Texas, 347 U.S. 475 (1954); Akins v. Texas, 325 U.S. 398 (1945); Hill v. Texas, 316 U.S. 400 (1942); Pierre v. Louisiana, 306 U.S. 354 (1939); Norris v. Alabama, 294 U.S. 587 (1935); Strauder v. West Virginia, 100 U.S. 303 (1880).

${ }^{2}$ See Collins v. Walker, 329 F.2d 100, aff'd on rehearing, 335 F.2d 417 (5th Cir.), cert. denied, 379 U.S. 901 (1964). In only one other case, State v. Green, 221 La. 713, 60 So. 2d 208 (1952), was the deliberate inclusion issue squarely met. In that case the inclusion was considered harmless because it did not specifically limit the number of Negroes to be chosen. Other cases in wbich the inclusion issue has been raised have been decided on non-constitutional grounds. See United States ex rel. Mack v. Walker, 231 F. Supp. 819 (E.D. La. 1964) (systematic inclusion not shown); United States ex rel. Davis v. Davis, 229 F. Supp. 649 (E.D. La. 1964) (systematic inclusion not shown); State v. Mack, 243 La. 369, 144 So. 2d 363 (1962), cert. denied, 373 U.S. 917 (1963) (systematic inclusion not shown); Brooks v. State, 170 Tex. Crim. 555, 342 S.W.2d 439 (1960) (procedural grounds); Haraway v. State, 203 Ark. 913, 159 S.W.2d 733, cert. denied, 317 U.S. 648 (1942) (procedural grounds).

${ }^{3}$ I5 U.S.C.M.A. 31,35 C.M.R. 3 (1964).

Id. at $35-36$.

"Brief for Appellant, p. 33. The defendant contended that the procedure employed was potentially prejudicial because of the "sometimes over-ready complaisance" of members of his race. Ibid.

- Brief for Appellant, pp. 32-33. The Government did not argue the merits of the inclusion issue, contending that the question could not be considered because the court had originally limited its review to a companion issue, involving the exclusion of members of lower enlisted grades from the court-martial board. Brief for Appellee, p. 8 n.l. The court ignored this contention and decided both questions. 15 U.S.C.M.A. at 40-41,

7 The opinion of the court found the procedure of deliberate inclusion permissible under the federal constitution. 15 U.S.C.M.A. at 34 (Quinn, C.J.). Judge Kilday con- 
defendant's rights had not been abridged as the procedure not only assured a "representative" board, but discriminated in favor of the defendant.8

Military trials have not traditionally been clothed with the constitutional safeguards applicable to civilian trials, ${ }^{0}$ but have been governed by Congress under its constitutional power to regulate the land and naval forces. ${ }^{10}$ Although Congress has expressly afforded the convening authority broad discretion in the appointment of court-martial boards, ${ }^{11}$ the opinion of the court in Crawford declined to predicate its decision on a distinction between military and civilian selection procedures. ${ }^{12}$ Instead, a majority of the court considered the discretion of the appointing officer to be circum-

curred on the basis of statutory interpretation, arguing that the Constitution was inapplicable. Id. at 42. The dissent agreed with the opinion of the court to the extent that the federal constitution controlled, but found the procedure unconstitutional. Id. at 52 (Ferguson, J.).

${ }^{8}$ Id. at 41 .

- See Reid v. Covert, 354 U.S. 1, 36-39 (1957); Burns v. Wilson, 346 U.S. 187, 140 (1953); Warren, The Bill of Rights and the Military, 37 N.Y.U.L. REv. 181, 187 (1962). It is well-settled that the sixth amendment right to a trial by jury is inapplicable to courts-martial. See, e.g., Whelchel v. McDonald, 340 U.S. 122, 127 (1950); Ex parte Quirin, 817 U.S. 1, 40 (1942); Kahn v. Anderson, 255 U.S. 1, 8.9 (1921). Furthermore, the fifth amendment expressly excludes from the requirement of indictment by grand jury those cases arising in the land and naval forces.

${ }^{10}$ U.S. CoNST. art. I, \& 8. See Burns v. Wilson, supra note 9; 15 U.S.C.M.A. at 41 (1964) (concurring opinion). The courts have considered Congress better equipped to balance the demand for military discipline with the necessity for procedural safe. guards. See Burns v. Wilson, supra note 9; Warren, supra note 9, at 187. In 1950, Congress enacted comprehensive legislation to regulate military trial procedure embodying many of the constitutional protections. Uniform Code of Military Justice, 64 Stat. 108 (1950), as amended, 70A Stat. 36 (1956), 10 U.S.C. $\$ \S 801-940$ (1958). At that time Con. gress established the Court of Military Appeals, describcd by Chief Justice Warren as a "civilian 'Supreme Court' of the military." Warren, supra note 9, at 188.

${ }^{21}$ Selection of court-martial board members is vested in an officer called the con. vening authority who is authorized to appoint those persons who "in his opinion" are best qualified for the duty by reason of "age, education, training, experience, length of service, and judicial temperament." Uniform Code of Military Justice, 10 U.S.C. 825 (d) (2) (1958).

${ }^{12}$ Less discretion is inherent in the civilian selection procedure. In the compilation of general venire lists a number of sources may be employed. See, e.g., Brown v. Allen, 344 U.S. 443, 474 (1953) (list of taxpayers permissible although it tends to exclude more Negro than white jurors); Moore v. New York, 333 U.S. 565 (1948) ("blue ribbon" jury). Ultimately, however, the names of grand and petit jurors are generally drawn by lot from either a jury wheel, a box or a book which include the general venire lists. See generally VANDERBILT, JUdGeS AND JURORs: THEIR Functions, Qualifications and Selection, 67-71 (1956); Vanderbilt, Minimum Standardos of Judicial Administration, 162-94 (1949); Comment, 13 Hastings L.J. 479 (1962); 56 Micr. L. REv. 954, 955 (1958). Nonetheless, the discretion afforded in the compilation of general venire lists may well allow a subtle "packing," thereby affecting the chance drawing. See Collins v. Walker, 329 F.2d 100, aff'd on rehearing, 335 F.2d 417 (5th Cir.), cert. denied, 379 U.S. 901 (1964). 
scribed by constitutional principles which have evolved in the selection of civilian jurors. ${ }^{13}$

Recent decisions of both the United States Supreme Court ${ }^{14}$ and the Court of Military Appeals ${ }^{15}$ have called for the application of constitutional guarantees in military trials, however, the extent of such protection has not been expressly delineated. ${ }^{10}$ Both courts have urged the application of "due process" in military trials, ${ }^{17}$ but the Court of Military Appeals has developed a concept of "military due process," once totally statutory in character, ${ }^{18}$ which is now said to emanate from standards enunciated in the Constitution. ${ }^{19}$ In Crawford, the plurality opinion expressly recognized that "constitutional due process" includes the right of a military defendant to be treated equally with other accused in the selection of triers of fact. ${ }^{20}$ However, the court held that the inclusionary practices were favor-

\footnotetext{
${ }^{23}$ See note 7 supra.

14 Burns v. Wilson, 346 U.S. 137, 142-43 held that the federal courts on habeas corpus may consider claims by servicemen that their constitutional rights have been denied in the military courts, if the latter have failed to consider the constitutional claim. Justices Douglas and Black, dissenting, were prepared to apply all of the provisions of the fifth amendment to military trials, except for the requirement of grand jury indictment. Id. at 152-54. Prior to Burns the Court had allowed servicemen review by habeas corpus only on narrow jurisdictional grounds. Warren, supra note 9, at 187. Chief Justice Warren, who was not a member of the Court at the time of the Burns decision, has said that the case recognizes that "our citizens in uniform may not be stripped of basic rights simply because they have doffed their civilian clothes," and that defendants may challenge deprivations of "fundamental rights" in courtsmartial. Warren, supra note 9 , at 188.

${ }^{26}$ See, e.g., United States v. Culp, 14 U.S.C.M.A. 199, 33 C.M.R. 411 (1963) (adequate counsel), 49 VA. L. REv. 1581, 1585-88; United States v. Jacoby, 11 U.S.C.M.A. 428, 29 C.M.R. 244 (1960) (right of confrontation). See Quinn, The United States Court of Military Appeals and Military Due Process, 35 ST. John's L. Rev. 225, 232, 241 (1961).

${ }^{10}$ Quinn, supra note 15, at 227-33; see Reid v. Covert, 354 U.S. 1, 36 (1957). The Court did state that a procedure which it approved in Swaim v. United States, 165 U.S. 553 (1897) would have been unconstitutional if double jeopardy protections were applicable to courts-martial. 354 U.S. at 36 n.68.

${ }^{17}$ See United States v. Wilson, 10 U.S.C.M.A. 337, 338-39, 27 C.M.R. 411, 412-13 (1959); United States v. Rawdon, 9 U.S.C.M.A. 396, 397, 26 C.M.R. 176, 177 (1958); United States v. Clay, 1 U.S.C.M.A. 74, 77, 1 C.M.R. 74, 77 (1951); Burns v. Wilson, 346 U.S. 137, 142-43 (1953) (dictum).

${ }^{18}$ See United States ex rel. Creary v. Weeks, 259 U.S. 336 (1922); Reaves v. Ainsworth, 219 U.S. 296, 304 (1911); De War v. Hunter, 170 F.2d 993, 997 (10th Cir. 1948); United States v. Clay, supra note 17; Comment, 64 Colum. L. REv. 127, 129-130, 137 (1964).

${ }^{10}$ See United States v. Jacoby, 11 U.S.C.M.A. 428, 430-31, 29 C.M.R. 244, 246-47 (1960); cf. United States v. Wilson, 10 U.S.C.M.A. 337, 338-39, 27 C.M.R. 411, 412-13 (1959). See Quinn, supra note 15, at 228-32, for a description of military due process. Chief Judge Quinn of the Court of Military Appeals stated that althougb military due process originates from the federal constitution, the concept is broader than civilian due process. Id. at 232.

20 I5 U.S.C.M.A. at 34.
} 
able to the defendant, and therefore "equal protection of the laws is not denied, but assured." 21 The court clearly appears to have incorporated equal protection guarantees into its application of "due process" protection, whether derived from the fifth amendment guarantees ${ }^{22}$ or from the broader concept of "military due process."

The more fundamental constitutional problem of deliberate inclusion raised by Crawford also was scrutinized in Collins $v$. Walker, ${ }^{23}$ which declared unconstitutional a similar practice in the selection of civilian jurors. ${ }^{24}$ The Collins court reiterated the familiar notion that a Negro stands equal before the law, and "is viewed by the law as a person, not as a Negro."25 However, the Crawford court expressly rejected Collins, intimating that the Fifth Circuit had failed to perceive a crucial difference between favorable discrimination and prejudicial discrimination. ${ }^{26}$

One requirement imposed by the equal protection cases is that federal and state classifications must bear a reasonable relationship to some legitimate governmental purpose; ${ }^{27}$ racial classifications in particular appear to be constitutionally "suspect."28 Thus, classifications employed to exclude Negroes from jury service consistently have been held to violate the fourteenth amendment. ${ }^{29}$ The Supreme Court has not ruled specifically on the inclusion issues before the courts in Crawford and Collins, but the logic and language of

\footnotetext{
21 Id. at 41 .

${ }^{22}$ Although the equal protection clause of the fourteenth amendment applies only to state action, the Supreme Court has applied the guarantees embodied therein to federal action under the due process clause of the fifth amendment. See Schncider v. Rusk, 377 U.S. 163, 168 (1964); Bolling v. Sharpe, 347 U.S. 497, 499 (1954); Pennsylvania R.R. v. Day, 360 U.S. 548, 554 (1959) (dissenting opinion).

${ }^{23} 329$ F.2d 100, aff'd on rehearing, 335 F.2d 417 (5th Cir.), cert. denied, 379 U.S. 901 (1964).

${ }^{24}$ In Collins, six Negroes were deliberately included in a group of twenty persons from which twelve grand jurors were drawn. Eleven of the jurors were selected by lot; the foreman was chosen by the judge. The resulting grand jury of seven whites and five Negroes returned a true bill against a Negro accused. Id, at 104. Having failed to include any Negroes on a previous grand jury, the jury commissioners were motivated in part by a desire to forestall systematic exclusion objections. State $v$. Collins, 242 La. 704, 715-18, 138 So. 2d 546, 551 (1962).

25329 F.2d at 105.

${ }^{20} 15$ U.S.C.M.A. at 41.

${ }^{27}$ E.g., Bolling v. Sharpe, 347 U.S. 497, 500 (1954) (segregated schools); Kotch v. Board of River Pilot Comm'rs, 330 U.S. 552, 556 (1947) (employment opportunity based on consanguinity); Yick Wo v. Hopkins, 118 U.S. 356, 373-74 (1886) (right to maintain business conditioned on race).

${ }^{28}$ E.g., Bolling v. Sharpe, supra note 27, at 499; Oyama v. California, 332 U.S. 633, 646 (1948); Korematsu v. United States, 323 U.S. 214, 216 (1944).

${ }^{20}$ See cases cited note 1 supra.
} 
its opinion in Cassell $v$. Texas ${ }^{30}$ lends support to the proposition that such a practice violates the requirements of equal protection. In Cassell the defendant challenged a racial quota system imposed in the selection of grand jurors. ${ }^{31}$ While designed to exclude more than one Negro on any given jury, and in fact challenged on that ground, in the absence of other exclusionary practices ${ }^{32}$ the system would seem to effectuate as well a deliberate incliusion of one Negro on most juries. The Court held that the defendant had been denied equal protection of the laws, stating broadly that "an accused is entitled to have charges against him considered by a jury in the selection of which there has been neither inclusion nor exclusion because of race."33 The Court stressed that jury members should be selected on the basis of individual qualifications without regard to their race. ${ }^{34}$

Although Cassell was decided on alternative grounds, ${ }^{35}$ its emphatic aversion to racial considerations in jury selection seems applicable to Crawford. ${ }^{36}$ With similar emphasis, the Court in Avery v. Georgia ${ }^{37}$ held that the use of colored tickets designating the race of prospective jurors was prima facie evidence of unconstitutional discrimination. ${ }^{38}$ The Court stated that jury commissioners

\footnotetext{
${ }^{80} 339$ U.S. 282 (1950).

32 Although no Negroes were actually included on the grand jury in Cassell, the defendant contended that the commissioners had established a pattern of consistently limiting Negroes to not more than one for each consecutive grand jury. The defendant claimed that the officials had interpreted past Court decisions as allowing a practice of deliberate limitation so long as it was approximately proportional to the number of Negroes eligible for grand jury service. Id. at 286.

${ }^{32}$ Other practices might include discriminating against Negroes in compiling jury lists, e.g., Norris v. Alabama, 294 U.S. 587 (1995), or in selecting jurors from the list, e.g., Avery v. Georgia, 345 U.S. 559 (1953).

3339 U.S. at 287. (Emphasis added.)

31 Id. at 286; id. at 295 (Frankfurter, J., concurring).

35 Besides the deliberate exclusionary and inclusionary aspects of the quota system, the Court pointed to a federal statute which prohibits discrimination in the selection of grand or petit jurors in any court of the United States or of any state. 18 U.S.C. $\$ 243$ (1958). The failure of the statute to include courts-martial specifically, and the separate regulation of military trials in the Military Code of Justice, 10 U.S.C. $\$ \S$ $801-940$ (1958) seem to exclude reference to the provisions in military trials. *

${ }^{30}$ On rehearing in Collins v. Walker, 335 F.2d 417, 420 (1964), the court held Cassell determinative of the issue of deliberate inclusion. The court emphasized that in both Cassell and Collins the fatal defect was the use of race as the basis of selection. The dissenting judge in Collins sought to distinguish Cassell on grounds that the case involved deliberate limitation, and argued that the language as to deliberate inclusion was mere dictum. Id. at 422-23. See also Navasky, The Benevolent Housing Quota, 6 How. L.J. 30, 54 (1961); Bennett, The Work of the Louisiana Supreme Court for the I949-1950 Term, 11 LA. L. REv. 141, 241 (1951); 59 MrCH. L. REv. 1054, 1069-70 (1961). ${ }^{37} 345$ U.S. 559 (1953).

${ }^{38} I d$. at 561; id. at 564 (Frankfurter, J., concurring).
} 
were under a constitutional duty to follow a "course of conduct" which did not discriminate on racial grounds in the selection of jurors. $^{39}$ In Crawford the court-martial convening authority had used lists containing names of Negroes marked by asterisks, a pro. cedure similar to that prohibited by Avery.40 Although the Craw. ford court distinguished Avery as a case dealing with exclusionary tactics, Avery's opposition to racial considerations in the process of assembling juries appears applicable whether the intent is to include or exclude.41 Moreover, it hardly seems inapposite to suggest that the same techniques used for deliberate inclusion of one Negro could be employed covertly for deliberate exclusion of more than one Negro. ${ }^{42}$

The opinion of the court in Crawford formulated a distinction between prejudicial and non-prejudicial discrimination, tacitly assuming that deliberate inclusion of a member of a defendant's race is not prejudicial.43 It appears that the court was employing a procedural concept to affirm the decision, for an absence of prejudice is normally sufficient to preclude reversible error.44 But there is Supreme Court authority to the effect that denial of a federal right suitably asserted requires reversing a conviction. ${ }^{46}$ Thus, even in the absence of actual prejudice, if it is assumed that a Negro defendant $^{46}$ has a federal right ${ }^{\mathbf{4 7}}$ to a court-martial selected without regard to racial criterion, his conviction arguably should be reversed.

\footnotetext{
${ }^{80} \mathrm{Id}$. at 561 .

${ }^{\circ}$ The officer in Crawford went even further by making a concerted and exhaustive search for a Negro court member when the lists proved unsatisfactory. 15 U.S.C.M.A. at 36,59 .

"See Collins v. Walker, 329 F.2d 100, aff'd on rehearing, 335 F.2d 417, (5th Cir.) cert. denied, 379 U.S. 901 (1964); United States v. Crawford, 15 U.S.C.M.A. at 58 (dissenting opinion).

4 There is no evidence that there was a direct effort to limit the number of Negroes chosen in Crawford. Indeed, another Negro was included on the board, but apparently not because of his race. See 15 U.S.C.M.A. at 49 . Nevertheless, the recognition of deliberate inclusion as a valid practice could well lead to disguised exclusion in other cases, particularly where the convening authority uses special symbols to designate Negroes.

- 15 U.S.C.M.A. at 51.

“ E.g., Naval v. United States, 278 F.2d 611, 614 (9th Cir. 1960); Bell v. United States, 251 F.2d 490, 494 (8th Cir. 1958); Bartley v. State, 210 Ark. 1061, 1068, 199 S.W.2d 965, 968 (1947); State v. Spears, 76 Wyo. 82, 98, 300 P.2d 551, 557 (1956).

${ }^{45}$ Norris v. Alabama, 294 U.S. 587, 599 (1935); see Griffin v. California, 380 U.S. 609 (1965); Bruno v. United States, 308 U.S. 287, 294 (1939) (statutory right). For state cases holding that violation of a constitutional right is never harmless error see Garcia v. State, 151 Tex. Crim. 593, 210 S.W.2d 574 (1948); McCulloch v. State, 13 So. 2d 829, 194 Miss. 851 (1943); cf. Kotteakes v. United States, 328 U.S. $750,764-65$ (1946).

${ }^{18} \mathrm{~A}$ defendant ordinarily has no standing to challenge a discriminatory action on
} 
Furthermore, the assumption that inclusion here was favorable discrimination ignores factors which may render the selection detrimental to the accused. White board members may resent the Negro's presence on the board ${ }^{48}$ if they are aware of the deliberate inclusion, and this resentment may be directed against the Negro defendant. Likewise, the Negro member who is aware of his deliberate inclusion may be inordinately unsympathetic to the accused in an effort to demonstrate fairness and objectivity to his appointing superiors. ${ }^{49}$

The opinion of the court in Crawford attempted to support the reasonableness of the classification by stressing that the deliberate inclusion assured a more "representative" court-martial board. Although the Supreme Court has indicated that federal juries representative of the community are desirable, ${ }^{50}$ its holdings that one may not demand a "mixed" or proportionate jury indicate the $a b$ sence of a constitutional requirement that specified groups be deliberately included to assure a racially representative jury. ${ }^{51}$ The achievement of "representative" juries may be a legitimate governmental purpose, but deliberate inclusion of members of specified races is an inappropriate means to that end because racial classification of jurors merely perpetuates the position of a Negro as separate and distinct before the law.

equal protection grounds unless he is a member of the class discriminated against. McCabe v. Atchison T. \& S.F. Ry., 295 U.S. 151, 162 (1914). But see Allen v. State, 110 Ga. App. 56, 137 S.E.2d 711 (1964) (white civil rights worker had standing to complain of systematic exclusion of Negroes from jury).

"The opinion of the court stated it was applying "constitutional due process," I5 U.S.C.M.A. at 34, although the concurring judge was applying statutory criteria solely. Id. at 42.

${ }^{8}$ See Comment, 72 Yale L.J. 559, 567 n.33 (1963).

- Cf. Greenberg, Race Relations and american Law 406, 408 (1959). This was one argument presented by the defendant in Crawford. See note 5 supra. But cf. Broeder, The Negro in Court, 1965 DukE L.J. 19, 29.

${ }^{\circ 0}$ E.g., Ballard v. United States, 329 U.S. 187 (1946); Thiel v. Southern Pac. Co., 328 U.S. 217 (1946).

s2 E.g., Cassell v. Texas, 339 U.S. 282 (1950); Virginia v. Rives, 100 U.S. 313 (1879). 